\title{
Enhance Tianfu Culture for Chengdu's Intercultural Communication
}

\author{
Wang Wei \\ ${ }^{1}$ Chengdu Institute of Public Administration, China \\ nonstopfly@qq.com
}

Keywords: City image, Tianfu Culture, Intercultural communication

\begin{abstract}
The purpose of this paper is to study the role of Tianfu culture in Chengdu's intercultural communication process, and its relationship with city image. To aid my analysis, I conducted open-ended interviews and collected secondary data to find the core of Tianfu culture is innovation, modernity, optimistic and kindness. Which could help Chengdu to build an important national creative culture center.
\end{abstract}

\section{Introduction}

City is one of the most important cells in modern society, which carries social culture and supports social economy development. With cities' growth, culture has become a kind of organizational form of productivity, which has shown its strong economic vitality, especially in the new technology flow. Culture is the unique mark of a city, the root and soul of a city. In the age of globalization, culture often been treated as the main position to spread the mainstream values of a city and enhance its international influence. The advantage of culture is that it is difficult to be replace and hard to be imitate, which make it has unique competitive advantage. With more and more effective interaction with economic development, culture is playing a vital role in urban economy growth. Based on its great potential, culture is treat as a special tool for government to sustain economic growth, improve people's well-being and promote social equity.

Different cities have different cultural performance. Because each city has its own social and economic conditions which cannot be the same as others. For example, Paris is knew as "fashion city", Los Angeles alias "movie city", Vienna is treated as "music city", etc. It seems that all the global famous cities have its own unique urban culture, which has been shaped as their special distinguishing feature for hundreds of years. Unique urban culture carries cities' basic value pursuit and original roots, which helps others to understand their citizens' spirit.Chengdu city has a history of more than 4500 years. It has not changed its name and center for 2,300 years, which makes it quite special in Chinese history. As one of the first historical and cultural cities in China, Chengdu has rich cultural resources and diverse forms such as panda, Sichuan silk and many intangible cultural heritages. Addition to this, Chengdu is one of the most important cities in Western China, which has been treat as the national center city of China recently. Therefore, Chengdu has no choice but to shoulder its historical task and challenge. Chengdu's aspiration should not only to become the economic and technology center, but also to be the creative and foreign communication center in Western China. More importantly, Chengdu's final ambition is to be a global famous cultural city.

However, there are still some problems for Chengdu's intercultural communication. Firstly, Chengdu city did not create its certain and unique city image. Chengdu, like Dalian, Qingdao and many other tourist cities, has been dubbing "charming", "vitality", "leisure", which make itself lack of personality and differences. Chengdu, also be treated as "leisure city" and "city of delicious food", and "wealth city", define too much make it hard to be remembered by the audience. Therefore, the overseas tourists cannot realize the difference between Chengdu and other cities. Secondly, Chengdu pays more attention on the domestic audience rather than overseas. Due to the self-preference and the unconscious of self in the process of communication, the misunderstanding 
has appeared such as "Chengdu culture is the ancient Bashu culture", "Chengdu culture is the object culture", etc. These misunderstand separates culture form the past to the present, from the reality to the virtual, which makes Chengdu's spirit been fragment without a fully and correct understanding. Therefore, the government has put forward to enhance unique Tianfu culture for Chengdu, so that the world can comprehend Chengdu and its culture more effectively.

\section{Research questions}

RQ1: What is core point of Tianfu culture?

RQ2: How could Chengdu use Tianfu culture for intercultural communication?

\section{Methodology}

The open-ended interview was chose to find answers to the research questions. My primary focus is to study the concept of Tianfu culture. Therefore, most of my interviewees are local people. I also invited some foreigners to do interviews because their cultural backgrounds are quite different from the locals, which can provide a more wide view to comprehend Tianfu culture. Addition to this, I also collected some secondary data to make better understanding of Tianfu culture.

\section{Results}

Tianfu, as we know, is the alias of Chengdu, Tianfu culture consist of eight words, which represents Chengdu's characteristic from four dimensions. Therefore, Chengdu need to be refined its image to make people realize that Chengdu is truly extraordinary.

\subsection{Innovation \& Creation - the driving force behind cultural industry}

Two thousand years ago, Li Bing and his son built Dujiangyan water conservancy project, which is treat as a miracle in human's long history. The first paper money known as "Jiao Zi" was also born in Chengdu. Nowadays, the world creative week also chose Chengdu as the permanent address. Chengdu has always been a city full of innovation and creation. In the year of 2016, the city spent 25.8 billion yuan on research and development, a huge increase than last year. The number of new market participants was 335, 000, which had increase about $34.6 \%$ compared with last year. A large number of advanced technologies with high technical content and strong industrial belt have settled in Chengdu, which providing strong project support for the future development of the city.

\subsection{Modernity \& Elegance- city's cultural atmosphere}

Tokyo has Ginza, New York has Saks Fifth Avenue, Beijing has Sanlitun. When it comes to fashion landmarks, Chengdu also has its own international fashion houses, such as Chunxi Road and Taikoo Li district. Relevant data shows that based on the international first-line brand stores and brands numbers, Chengdu ranks China's third place. There are about 110 brands operates more than 200 stores. Take Louis Vuitton for example, the LV stores in Chengdu's annual sales performance has also been ranks the top three in China. No matter you are local Chengdu citizen, or foreign tourists, when you are walking around there, you cannot failed to find a "teahouse" because it is play an irreplaceable role in this city. It is their life style, which make them easy and happy go lucky. Therefore, Chengdu has the highest number of teahouse in the world. The demand for tea in Chengdu is usually the highest in China.

\subsection{Optimistic \& Inclusiveness - citizen's cultural spirit}

The cultural heritage of Chengdu is quite thick, which makes it different from other cities. Citizens in Chengdu have been influencing by Confucianism, Buddhism and Taoism deeply. Therefore, they 
prefer to pay more focus on the quality of life rather than material wealth. This is the Taoism's idea. Addition to this, citizens in Chengdu are modesty and good at relief their daily stress, which borrows Buddhism's wisdom. Draw attention to Confucianism, Chengdu has huge number of poets and painters in history such as Li Bai, Du Fu and Su Shi. They made huge contribution to their country and been remembered for thousands of years. "An Yi" and "Ba Shi" are two common words in Sichuan dialect, which means feel comfort and good. It has also become the impression of many outsiders on Chengdu. In fact, it is the mentality optimistic character, simple attitude and inclusiveness of Chengdu's spirit.

\subsection{Kindness \& Charity-citizens' cultural attitude}

In the year of 2017 , there are more than 16 countries have established consulates in Chengdu, including Germany, France and the United States. Up to now, the number of Chengdu's international friendship city rose to 34 and more than 50 friendly cooperative cities have signed bilateral treaty with Chengdu. Addition to this, Chengdu has opened 103 international and regional airline routes with 85 countries and regions. In order to make a more convenient environment for immigrant people. Chengdu has published an English book named "A Guidebook for Foreigners Living in Chengdu". This book provides many useful tips for foreigners, which shows Chengdu is trying its best to attract people to settle down. Therefore, "Chengdu Drifters" has become a new trend in China. The city is opening its door to all kinds of people no matter where you come from.

\section{Conclusion and discussion}

Although Chengdu has refined Tianfu culture, it does not mean the city's work has finished. Instead, Chengdu's intercultural communication process is just on the road. Following are some advice for Chengdu.

\subsection{Make use of big events to spread Tianfu culture}

In the process of the dissemination of urban image, it is a common method to promote the public's attention by make use of big events. For example, Chengdu can try to hold "experience ambassadors" and such activities. By inviting foreign celebrities, internet celebrities, especially opinion leaders and international volunteers to live in Chengdu for some days. Then, they can tell their stories in Chengdu, they can share their true idea and direct feeling about this city in their mother tongue. The Chengdu story told by western scholars and people, which can be more easily for foreigners to accept. Therefore, Chengdu's attraction will have a huge increase, because more and more people want to touch and feel this city. However, borrowing events' influence is not simply by transplanting external forces, it needs seeking the combination of potential bonding point according to the city's resource situation and its own characteristics. By use these events, Chengdu can be accepted by overseas people in a more comfortable way. Besides, it will help Tianfu culture go out and gain recognition from overseas audiences more effectively.

\subsection{Use internet technology to create Tianfu culture brand}

The power of city branding is to make people know and remember a certain area, which will help to associate some exact images with the existence of the city and let its spirit be integrated into every building around this city. Besides, it will provide competition and life coexist with this city. The establishment of Tianfu culture brand needs to make use of advantages of internet technology. The most prominent feature of new media is personalization and infinite sharing, which can meet different demands of different audiences. Addition to this, Chengdu should try to use full media to integrate the resources of the global mainstream media and finally establish a simultaneous 
full-media communication net for connecting domestic and abroad. In particular, Chengdu should make full use of overseas social media, like Facebook, Twitter, Instagram and other software, especially by using some popular method like autodyne video and online live broadcast to maximize the "celebrity's effect" and to enhance the communication effect.

\subsection{Borrow the secondary transmission chance for Tianfu culture}

Secondary transmission means a media of information product not only be spread by its own platform but also be used by other media at the same time, especially for some big and popular media, which is more easy for target audience to accept. In the past, the secondary transmission emphasized the number and frequency of the foreign media reprinting in domestic media. However, secondary transmission is not simple copy nor translation. It needs base on the audience and the domestic media's characteristics and follow certain communication rules. Through a creative way to change the content of the manuscript appropriately and bring overseas media's articles back to Chengdu.

\section{Acknowledgement}

This research was financially supported by the Chengdu Planning Office of Philosophy and Social Science (Project NO.2018B06).

\section{References}

[1] E. Avraham, Media strategies for improving an unfavorable city image. Cities, vol.2, pp. 471-479, 2004.

[2] A. Vailaya, A. Jain \& H. J. Zhang, On image classification: city images vs. landscapes. Pattern Recognit, vol.3, pp. 75-84, 1998.

[3] K. D. Kappus, J. S. Marks, R. C. Holman, J. K. Bryant, C. Baker, and G. W. Gary, et al., An outbreak of norwalk gastroenteritis associated with swimming in a pool and secondary person-to-person transmission. American Journal of Epidemiology, vol.116, pp. 834-839, 1982.

[4] R. Scollon, S. W. Scollon, and R. H. Jones, Intercultural communication: a discourse approach. Tesol Quarterly, vol.30, pp. 366-368, 2012.

[5] T. R. Williams, Exploring the impact of study abroad on students' intercultural communication skills: adaptability and sensitivity. Journal of Studies in International Education, vol.9, pp. 356-371, 2005.

[6] M. Trueman, M. Klemm, and A. Giroud, Can a city communicate? bradford as a corporate brand. Corporate Communications An International Journal, vol.9, pp. 317-330, 2004.

[7] C. Herington, B. Merrilees, D. Miller, and T. Abimbola, Multiple stakeholders and multiple city brand meanings. European Journal of Marketing, vol.46, pp. 1032-1047, 2012. 